\title{
HUBUNGAN KADAR ZINK DALAM ASI DENGAN BERAT BADAN DAN PANJANG BADAN BAYI USIA 4-6 BULAN DI KOTA PADANG SUMATERA BARAT
}

\author{
Ratnadewi \\ AKBID PASBAR \\ Email:zuratdefu@yahoo.co.id
}

\begin{abstract}
Zinc deficiency is public health problem. Almost two million people in developing country suffered zinc deficiency. Zinc deficiency in Indonesia, 25\% in breastfeeding mothers and $17 \%$ in babies. The purpose of this study was to determine the correlation of zinc level in breastmilk with 4-6 months old baby weight and length in Padang City West Sumatera. This study was done in working area of Lubuk Buaya, Padang Pasir, and Nanggalo Public Health Center. This study was done from January 2016 until January 2017. The design of this study was cross sectional, number of sample were 108 people. Samples were selected by simple random sampling. Zinc level in breastmilk was checked by AAS (Atomic Absorption Spectrophotometer). Data were analyzed by using univariate and bivariate with pearson correlation test. The correlation test, correlation was positive and patterned between log zinc level in breastmilk with 4-6 months old baby weight $(r=0,272)$, while the length $(r=0,216)$, correlation was positive and weak with $p$ value $<0,05$. That there were significant correlation between log zinc level in breastmilk and 46 months old baby weight and length.
\end{abstract}

Keywords: Breastmilk, Maternal Breastfeeding, Length, Weight, Zinc Level

\begin{abstract}
ABSTRAK
Kekurangan seng adalah masalah kesehatan masyarakat. Hampir dua juta orang di negara berkembang menderita kekurangan seng. Kekurangan zinc di Indonesia, $25 \%$ pada ibu menyusui dan $17 \%$ pada bayi. Tujuan dari penelitian ini adalah untuk mengetahui hubungan kadar seng dalam ASI dengan berat dan panjang bayi 4-6 bulan di Kota Padang Sumatera Barat. Penelitian ini dilakukan di wilayah kerja Puskesmas Lubuk Buaya, Padang Pasir, dan Nanggalo. Penelitian ini dilakukan mulai Januari 2016 hingga Januari 2017. Desain penelitian ini adalah cross sectional, jumlah sampel 108 orang. Sampel dipilih dengan simple random sampling. Kadar seng dalam ASI diperiksa oleh AAS (Atomic Absorption Spectrophotometer). Data dianalisis dengan menggunakan univariat dan bivariat dengan uji korelasi pearson. Uji korelasi, korelasi positif dan berpola antara kadar log zinc pada ASI dengan berat bayi 4-6 bulan $(r=0,272)$, sedangkan panjang $(r=$ $0,216)$, korelasinya positif dan lemah dengan nilai $\mathrm{p}<0,05$. Bahwa ada korelasi yang signifikan antara tingkat log zinc dalam ASI dan berat dan panjang bayi 4-6 bulan.
\end{abstract}

Kata kunci : ASI, Berat Badan, Ibu Menyusui, Level Zink, Panjang Badan 


\section{PENDAHULUAN}

Air Susu Ibu (ASI) merupakan makanan alamiah untuk bayi dan mengandung gizi yang lengkap, mudah dicerna, dan diabsorpsi. ASI mengandung zat anti infeksi dan anti alergi.

World Health Organization (WHO), 2010 memperkirakan hanya $40 \%$ dari seluruh bayi didunia yang mendapatkan ASI eksklusif untuk jangka waktu 6 bulan. Sedangkan menurut hasil laporan Riskesdas tahun 2010 di Indonesia melaporkan jumlah bayi yang mendapatkan ASI eksklusif sebanyak 15,3\%.

Masalah gizi pada hakikatnya adalah masalah kesehatan masyarakat. Salah satunya adalah masalah mengenai defisiensi zat gizi mikro seperti defisiensi zink. Golongan yang paling rentan kekurangan zink adalah bayi, anakanak, ibu hamil, dan ibu menyusui. Hampir 2 juta orang di negara berkembang kekurangan zink. Hal ini disebabkan tingginya kebutuhan nutrisi pada golongan tersebut. Defisiensi zink selalu dihubungkan dengan berkurangnya pertumbuhan pada bayi dan anak di negara berkembang. Retardasi pertumbuhan mempunyai prevalensi yang tinggi pada anak. Lebih kurang $43 \%$ anak usia di bawah 5 tahun di dunia $( \pm 230$ juta anak) adalah pendek.

Zink merupakan ion struktural dari membran biologi dan berkaitan erat dengan sintesis protein. Zink berperan dalam ekspresi gen dan fungsi endokrin, mekanisme zink dalam sintesis DNA, RNA, dan pembelahan sel. Zink juga berinteraksi dengan hormon yang berperan dalam pertumbuhan tulang seperti somatomedin-c, osteocalcin, testosteron, hormon tiroid dan insulin. Konsentrasi zink dalam tulang sangat tinggi dibanding dalam jaringan lain sehingga merupakan komponen penting dari matriks tulang. Zink juga membantu vitamin D dalam metabolisme tulang melalui stimulasi DNA dalam sel tulang. Selain itu zink juga berpartisipasi dalam proses metabolisme karbohidrat, protein, dan lemak dalam proses pertumbuhan. Zink di dalam plasma hanya $0,1 \%$, sedangkan kadar zink dalam ASI untuk umur bayi $4-6$ bulan adalah 0,135-0,120 mg/100 ml.

Penelitian ini bertujuan untuk untuk mengkaji hubungan kadar zink dalam ASI dengan berat badan dan panjang badan bayi usia $4-6$ bulan Di Kota Padang Sumatera Barat.

\section{METODE PENELITIAN}

Penelitian ini telah dilakukan di wilayah kerja Puskesmas Lubuk Buaya, wilayah kerja Puskesmas Padang Pasir, dan wilayah kerja Puskesmas Nanggalo. Pemeriksaan Kadar Zink dalam ASI telah dilakukan di Laboratorium Terpadu Kopertis Wilayah X Padang dengan waktu penelitian dimulai pada bulan Januari 2016 sampai Januari 2017. Penelitian ini merupakan penelitian kuantitatif dengan desain"cross sectional". Populasi pada penelitian ini adalah semua ibu yang mempunyai bayi usia 4-6 bulan, sampel yang digunakan adalah ibu yang mempunyai bayi usia 4-6 bulan yang sesuai dengan kriteria inklusi, Jumlah sampel adalah 108 orang. Teknik pengambilan sampel 
menggunakan teknik Simple Random Sampling (Acak sederhana).

Penelitian dilakukan setelah mendapatkan kelayakan etik dari komite etik penelitian Fakultas Kedokteran Universitas Andalas Padang. Selanjutnya peneliti mengajukan surat izin penelitian ke Dinas Kesehatan Kota Padang dan ke Puskesmas. Selanjutnya peneliti memilih 3 Puskesmas (wilayah kerja Puskesmas Lubuk Buaya, wilayah kerja Puskesmas Padang Pasir, dan wilayah kerja Puskesmas Nanggalo). Penelitian dilakukan bekerja sama dengan ahli kimia di Laboratorium Terpadu Kopertis Wilayah X Padang untuk pemeriksaan kadar zink dalam ASI dan Penelitian dilapangan bekerjasama dengan bidan untuk memeras ASI ibu dan ahli gizi untuk menimbang berat badan dan panjang badan bayi. Ibu yang memenuhi syarat inklusi penelitian akan diambil sebagai subjek penelitian dan dan diberi penjelasan sebelum persetujuan tentang penelitian yang akan dilakukan. ASI ibu di ambil dengan cara diperah atau dengan pompa ASI (sesuai dengan keinginan pasien) pada pagi hari pukul: 08.00 WIB sampai pukul 12.00 WIB. Selanjutnya ditimbang berat badan bayi dan mengukur panjang badan bayi.

Langkah berikutnya dilakukan pemeriksaan kadar zink dalam ASI dengan didestruksi asam nitrat hingga jernih dan berwarna kekuningan. Larutan hasil destruksi diukur dengan menggunakan AAS (Atomic Absorption Spectrophotometer). Data di analisa secara univariat dan bivariat. Sebelum melakukan analisa bivariat, dilakukan uji normalitas pada data yang berskala rasio yaitu kadar zink dalam ASI, berat badan bayi, dan panjang badan bayi usia 4-6 bulan dengan menggunakan uji kolmogorov smirnov, untuk mengetahui distribusi data penelitian.

\section{HASIL DAN PEMBAHASAN}

Dalam penelitian ini, ditemukan data kadar zink dalam ASI tidak terdistribusi normal $(\mathrm{p}<0,05)$, sehingga dilakukan transformasi data untuk menormalkan distribusi data kadar zink dalam ASI tersebut dengan log 10 sehingga data kadar zink dalam ASI terdistribusi normal. Untuk melihat log kadar zink dalam ASI dengan berat badan dan panjang badan bayi usia 4-6 bulan maka digunakan uji korelasi pearson.

Hasil penelitian didapatkan bahwa lebih dari separoh responden $(55,6 \%)$ berada dalam usia reproduksi sehat, sebagian besar responden $(75 \%)$ memiliki pekerjaan sebagai ibu rumah tangga, hampir separoh responden $(47,2 \%)$ berpendidikan SMU atau sederajat, dan hampir semua responden $(95,4 \%)$ memiliki riwayat persalinan normal. bayi rata-rata berumur 4,26 hari $\pm 0,5$, sedangkan rata-rata berat badan lahir bayi adalah 3240,2 $\mathrm{gr} \pm$ 397,3, sedangkan panjang badan lahir bayi adalah 48,6 $\mathrm{cm} \pm 1,5$. Sementara itu rata-rata berat badan bayi usia 4-6 bulan adalah 6683,3 gr $\pm 784,1$ dan rata-rata panjang badan bayi usia 4-6 bulan $64,8 \mathrm{~cm} \pm$ 2,5. Serta kadar zink dalam ASI memiliki rata-rata $0,2 \mathrm{mg} / 100 \mathrm{ml} \pm$ 0,15 . 
Tabel 1 Korelasi Log Kadar Zink dalam ASI dengan Berat Badan Bayi Usia 4-6 Bulan Di Kota Padang Sumatera Barat

\begin{tabular}{lcc}
\hline \multirow{2}{*}{ Variabel } & \multicolumn{2}{c}{$\begin{array}{c}\text { Berat Badan Bayi } \\
\text { Usia 4-6 Bulan (gr) }\end{array}$} \\
\cline { 2 - 3 } & $\mathrm{R}$ & $\mathrm{p}$ value \\
\hline $\begin{array}{l}\text { Kadar Log Zink } \\
\text { dalam ASI } \\
(\mathrm{mg} / 100 \mathrm{ml})\end{array}$ & 0,272 & 0,004 \\
\hline
\end{tabular}

Dapat dilihat bahwa Korelasi log kadar zink dalam ASI dengan berat badan bayi usia 4-6 bulan sebesar $(r=0,272)$. Terdapat korelasi sedang dan berpola positif, serta hasil yang didapatkan adalah signifikan antara log kadar zink dalam ASI dengan berat badan bayi usia 4-6 bulan $(\mathrm{p}<0,05)$.

Tabel 2 Korelasi log kadar zink dalam ASI dengan Panjang Badan Bayi Usia 4-6 Bulan Di Kota Padang Sumatera Barat

\begin{tabular}{lcc}
\hline Variabel & $\begin{array}{c}\text { Panjang Badan } \\
\text { Bayi Usia 4-6 } \\
\text { Bulan }\end{array}$ \\
\cline { 2 - 2 } & $\mathrm{r}$ p value \\
\hline $\begin{array}{l}\text { Kadar Zink dalam } \\
\text { ASI (mg/100 ml) }\end{array}$ & 0,216 & 0,025 \\
\hline Dapat dilihat bahwa Korelasi & baho \\
log kadar zink dalam ASI dengan \\
panjang badan bayi usia 4-6 bulan \\
sebesar (r=0,216). Terdapat korelasi \\
lemah dan berpola positif, serta hasil \\
yang didapatkan adalah signifikan \\
antara log kadar zink dalam ASI \\
dengan panjang badan bayi usia 4-6 \\
bulan (p<0,05).
\end{tabular}

\section{Karakteristik Responden}

Karakteristik responden terdiri dari umur ibu, pekerjaan, pendidikan, dan riwayat persalinan. Umur ibu berada dalam umur reproduksi sehat. Tingkat pendidikan ibu tergolong sedang karena pendidikan rata-rata SMA atau sederajat. Ibu kebanyakan tidak bekerja atau ibu rumah tangga sehingga perolehan penghasilan pada umumnya bersumber dari bapak. Riwayat persalinan ibu pada umumnya adalah normal.

Rata-rata berat badan lahir bayi adalah 3240,2 gr $\pm 397,3$, sedangkan panjang badan lahir bayi adalah 48,6 $\mathrm{cm} \pm 1,5$. Berat badan merupakan salah satu indikator kesehatan Bayi Baru Lahir (BBL). Rata-rata berat badan bayi baru lahir yang ditemukan dalam penelitian ini berada dalam kisaran normal. Ratarata berat badan normal (usia gestasi $37 \mathrm{~s} / \mathrm{d} 41$ minggu) adalah 3200 gram (Kosim, 2012). Sementara itu ratarata panjang badan lahir yang didapatkan dalam penelitian juga berada dalam kisaran normal. Saat baru lahir, panjang badan normal bayi adalah sekitar $45 \mathrm{~cm}-55 \mathrm{~cm}$.

Pada penelitian ini ditemukan rata-rata kadar zink dalam ASI ibu adalah $0,2 \mathrm{mg} / 100 \mathrm{ml} \pm 0,15$. Hal ini menunjukkan bahwa angka yang dari dalam batas normal. Di dalam teori didapatkan bahwa kadar zink dalam ASI ketika bayi berumur 4-6 bulan adalah 0,135-0,120 mg/ $100 \mathrm{ml}$. Kadar zink dalam ASI berbeda-beda tergantung dari umur bayi. Semakin bertambah umur bayi maka semakin rendah kadar zink dalam ASI.

Dari beberapa penelitian di dunia, terdapat perbedaan kadar zink ASI ibu menyusui, seperti di negara Australia melaporkan bahwa kadar zink dalam ASI yaitu $0,5 \mathrm{mg} / \mathrm{L}$ pada usia bayi 12-20 minggu setelah melahirkan, di Kanada 2,0 mg/L (Mahdevi, 2010). Pada penelitian 
yang dilakukan oleh andrade MTS, et al (2014) menemukan kadar zink dalam ASI ibu menyusui adalah 0,2 $\mathrm{mg} / \mathrm{L}$ sedangkan menurut Komite pangan dan dan gizi Amerika mengukur volume ASI ibu di Amerika pada tahun pertama setelah melahirkan adalah 0,78 L/hari dengan kadar zink ASI pada 4 minggu adalah $2,75 \mathrm{mg} / \mathrm{L}$, pada 8 minggu adalah $2 \mathrm{mg} / \mathrm{L}$, pada 12 minggu adalah $1,5 \mathrm{mg} / \mathrm{L}$, dan 24 minggu adalah $1,2 \mathrm{mg} / \mathrm{L}$. Berdasarkan hal ini maka dibutuhkan tambahan zink 1,4 $\mathrm{mg} /$ hari pada 0-3 bulan, 0,8 mg/hari pada 3-6 bulan, dan $0,5 \mathrm{mg} /$ hari setelahnya (Brown et $a l, 2004)$. Hal ini disebabkan karena perbedaan daerah, asupan makanan, suplementasi sehingga menyebabkan adanya perbedaan kadar zink ASI ibu menyusui.

Rata-rata berat badan bayi usia 4-6 bulan adalah 6683,3 gr $\pm 784,1$ dan rata-rata panjang badan bayi usia 4-6 bulan adalah $64,8 \mathrm{~cm} \pm 2,5$. Pengukuran antropometri (berat badan dan panjang badan) pada bayi adalah salah satu bentuk penilaian status gizi bayi. Menurut Supariasa (2012), status gizi adalah ekspresi dari keadaan keseimbangan dalam bentuk variabel tertentu, atau perwujudan dari nutrisi dalam bentuk variabel tertentu.

Menurut Penelitian yang dilakukan di Baltimore, Washington didapatkan bahwa bayi yang diberikan ASI eksklusif berat badannya normal dibandingkan bayi yang tidak mendapatkan ASI eksklusif. Hal ini disebabkan karena kandungan nutrisi yang terdapat pada ASI sudah memenuhi kebutuhan dari bayi hingga umur 6 bulan. Sedangkan menurut penelitian yang dilakukan oleh Fitri DI, dkk (2014) di Indonesia menemukan hal yang berbeda bahwa hubungan pemberian ASI tidak signifikan dengan pertumbuhan bayi, hal ini berkemungkinan disebabkan oleh kuantitas dan kualitas ASI yang diberikan ibu yang masih kurang dan belum memenuhi kebutuhan bayi sehingga penambahan berat badan dan panjang badan bayi menjadi tidak optimal. Selain itu faktor gizi pada ibu saat hamil dan menyusui, cara menyusui yang belum tepat dan benar sehingga produksi ASI tidak sempurna.

Berat badan merupakan ukuran antropometri yang terpenting, dipakai pada setiap kesempatan memeriksa kesehatan anak pada semua kelompok. Berat badan dapat dipakai sebagai indikasi yang terbaik pada saat ini untuk mengetahui keadaan gizi dan tumbuh kembang anak, sensitif terhadap perubahan sedikit saja, pengukuran objektif dan dapat diulangi, dapat digunakan timbangan apa saja yang relatif murah, mudah dan tidak memerlukan banyak waktu (Soetjiningsih, 2007).

Tinggi Badan (TB) atau merupakan parameter paling penting bagi keadaan yang telah lalu dan keadaan sekarang, jika umur tidak diketahui dengan tepat. Tinggi badan juga merupakan ukuran kedua yang penting, karena dengan menghubungkan berat badan terhadap tinggi badan (quac stick) faktor umur dapat dikesampingkan. Tinggi badan untuk anak kurang dari 2 tahun sering disebut dengan panjang badan (Supariasa, 2012). dengan Berat Badan Bayi Usia 4-6 


\section{Bulan Di Kota Padang Sumatera Barat}

$\begin{array}{ccr}\text { Hasil } & \text { penelitian } & \text { ini } \\ \text { menunjukkan } & \text { korelasi } & \text { sedang } \\ (\mathrm{r}=0,272) \text { dan } & \text { berpola } & \text { positif. }\end{array}$
Berdasarkan uji statistik, hasil yang didapatkan adalah signifikan antara log kadar zink dalam ASI dengan berat badan bayi usia 4-6 bulan ( $\mathrm{p}<$ $0,05)$.

Hal ini sesuai dengan penelitian yang dilakukan oleh Xiang, et al (2007) yang menemukan adanya hubungan antara kadar zink dalam ASI dengan berat badan bayi. Zink yang biasanya juga disebut dengan Seng merupakan zat gizi yang esensial dan telah mendapat perhatian yang cukup besar. Zink berperan di dalam bekerjanya lebih dari 10 macam enzim. Berperan di dalam sintesa Dinukleosida Adenosin (DNA) dan Ribonukleosida Adenosin (RNA), dan protein. Maka bila terjadi defisiensi zink dapat menghambat pembelahan sel, pertumbuhan dan perbaikan jaringan, sehingga akan berpengaruh pada berat badan dan tinggi badan.

Hasil penelitian ini juga sejalan dengan penelitian yang dilakukan Sezer, et al (2013), yang membuktikan bahwa kadar zink yang rendah dalam ASI berkaitan dengan rendahnya pengukuran berat badan bayi. Namun demikian, hasil penelitian ini tidak sesuai dengan penelitian yang dilakukan oleh Kuncoro, et al (2013) yang melakukan penelitian kohort retrospektif dari tahun 2002 yang menyimpulkan tidak terdapat perbedaan yang nyata antara pertambahan berat badan anak yang diberikan intervensi suplemen zink dan PMT, PMT, dan tanpa intervensi (kelompok kontrol). Perbedaan hasil ini disebabkan karena metode dan karakteristik responden yang digunakan berbeda dengan penelitian ini seperti pada penelitian yang dilakukan Kuncoro MA et al, responden yang digunakan adalah ibu hamil yang di suplementasi zink yang kemudian dilakukan pemantauan berat badan bayinya secara berkala sampai anak usia 9 tahun.

Dalam penelitian ini didapatkan kadar zink dalam ASI hanya berkontribusi $7,4 \%$ terhadap berat badan bayi usia 4-6 bulan dan $92,6 \%$ dari faktor lain yang tidak diteliti. Hal ini disebabkan karena pertumbuhan berat badan merupakan multifaktor. Ukuran berat badan merupakan indeks gizi dan pertumbuhan yang terbaik, terutama pada bayi. Terdapat banyak faktor yang mempengaruhi pertumbuhan berat badan antara lain faktor internal dan eksternal. Faktor internal terdiri dari ras atau etnik atau bangsa, keluarga, umur, jenis kelamin, genetik dan kelainan kromosom. Sedangkan faktor eksternalnya terdiri dari faktor pranatal (gizi ibu pada saat hamil, mekanis, toksin atau zat kimia, endokrin, radiasi, infeksi, stres, dan anoksia embrio) dan pascanatal (lingkungan biologis, lingkungan fisik, faktor psikososial, dan faktor keluarga serta adat istiadat).

Salah satu dari faktor pascanatal yaitu faktor gizi. Unsur gizi menjadi pengaruh yang dominan dalam pertumbuhan anak terutama pada awal kehidupan sampai berumur 12 tahun. Nutrisi yang dibutuhkan oleh bayi dapat dipenuhi dengan pemberian Air Susu Ibu 
(ASI). ASI merupakan pilihan optimal sebagai pemberian makan pada bayi karena mengandung nutrisi, hormon, faktor kekebalan, faktor pertumbuhan, dan anti inflamasi.

Pada bayi usia 4-6 bulan, pertambahan berat badannya sangat dipengaruhi oleh berat badan lahir dan praktek pengasuhan (praktek asuh pemberian ASI dan kesehatan). Dalam 3 bulan pertama kenaikan berat badan kira-kira $1 \mathrm{~kg}$ per bulan. Pada umur 5 bulan berat badan bayi mencapai 2 kali berat badan lahirnya. Sedangkan pada usia 6 bulan kenaikan berat badan $1 / 2 \mathrm{~kg}$ per bulan. Jadi bayi dengan berat badan lahir yang rendah memiliki kemungkinan lebih rendah pula berat badannya usia 4- 6 bulan dari bayi yang memiliki berat badan lahir normal.

Bayi yang mendapatkan ASI eksklusif pada usia 0-6 bulan memiliki berat badan yang lebih rendah dibandingkan bayi yang mendapatkan susu formula atau makanan pendamping lainnya diusia tersebut. Selain zink, kandungan makro nutrient dan mikro nutrient ASI lainnya juga mempengaruhi berat badan bayi, seperti karbohidrat, protein dan lemak serta vitamin dan mineral lainnya. Semua zat gizi ini saling terkait dalam mengoptimalkan pertumbuhan dan perkembangan bayi.

Praktek pengasuhan merupakan faktor yang tidak dapat dikesampingkan dalam mencapai berat badan bayi yang optimal, diantaranya praktek pemberian ASI dan praktek asuh kesehatan. Menurut Hasselquist (2006), jika bayi disusui kurang dari delapan kali dalam 24 jam maka bayi akan dapat mengalami dehidrasi dan masalah berat badan.

\section{Korelasi log kadar zink dalam ASI dengan Panjang Badan Bayi Usia 4-6 Bulan Di Kota Padang Sumatera Barat}

$\begin{array}{ccr}\text { Hasil } & \text { penelitian } & \text { ini } \\ \text { menunjukkan } & \text { korelasi } & \text { lemah } \\ (\mathrm{r}=0,216) \text { dan } & \text { berpola } & \text { positif. }\end{array}$
Berdasarkan uji statistik, hasil yang didapatkan adalah signifikan antara log kadar zink dalam ASI dengan panjang badan bayi usia 4-6 bulan $(\mathrm{p}<0,05)$.

Hal ini disebabkan karena zink berperan dalam reaksi yang luas dalam metabolisme tubuh, kekurangan zink akan berpengaruh banyak terhadap jaringan tubuh tertentu pada saat pertumbuhan.

Hasil penelitian ini senada dengan penelitian yang dilakukan oleh Dorea (1993) pada ibu menyusui di Brazil yang menyimpulkan ada hubungan yang signifikan antara kadar zink dalam ASI dengan pertumbuhan linear bayi.

Namun demikian, hasil yang didapatkan pada penelitian ini tidak konsisten dengan penemuan Orun, et al (2012) yang menyebutkan tidak ada hubungan yang signifikan antara kadar zink dalam ASI dengan panjang badan bayi. Perbedaan ini disebabkan karena dalam melakukan penelitian, Orun, et al tidak mengekslusi bayi yang lahir premature, sehingga penambahan panjang badan bayi menjadi tidak signifikan. Sementara dalam penelitian ini bayi yang dijadikan sampel adalah bayi yang lahir dengan cukup bulan.

Pada penelitian ini ditemukan bahwa kadar zink dalam ASI hanya 
berkontribusi $4,7 \%$ terhadap panjang badan bayi usia 4-6 bulan dan 95,3\% dari faktor lain yang tidak diteliti. Sama hal nya dengan berat badan, panjang badan juga merupakan multifaktor. Panjang badan merupakan indikator pertumbuhan yang secara bersama-sama dapat menggambarkan pertumbuhan seseorang. Faktor yang dominan yang juga berpengaruh terhadap panjang badan adalah tinggi badan orang tua dan asupan. Panjang badan lahir mempengaruhi pertambahan panjang badan bayi. Seseorang yang memiliki orang tua yang tinggi akan memiliki tinggi badan lebih tinggi dari mereka yang orangtua nya pendek. Begitu juga dengan asupan, tidak hanya zink yang mempengaruhi panjang badan, tetapi zat gizi lain seperti karbohidrat, protein dan lemak serta vitamin dan mineral lainnya jika dikonsumsi secara adekuat akan mampu

\section{DAFTAR PUSTAKA}

1. Agustian, L. Sembiring, T. dan Ariani, A. Peran zinkum terhadap pertumbuhan anak. Sari Pediatri. 2009; 11 (4): 244-9.

2. Almatsier, S. Gizi seimbang dalam daur kehidupan. Jakarta: PT Gramedia Pustaka Utama; 2011.

3. Almatsier, S. Prinsip dasar ilmu gizi. Jakarta: PT Gramedia Pustaka Utama; 2009.

4. Almatsier, S. Prinsip dasar ilmu gizi. Jakarta: PT Gramedia Pustaka Utama; 2004. mengoptimalkan tinggi badan seseorang.

\section{SIMPULAN}

Terdapat hubungan yang signifikan antara log kadar zink dalam ASI dengan berat badan dan panjang bayi usia 4-6 bulan.

\section{SARAN}

Disarankan untuk melakukan penyuluhan secara berkesinambungan tentang menyusui dan memberikan ASI ekslusif sampai bayi berumur 6 bulan. Kepada ibu diharapkan selalu memperhatikan asupan makanan dengan mengkonsumsi makanan yang seimbang dan beragam terutama makanan yang mengandung zink seperti daging, kerang, sayur bayam dan lain sebagainya.

5. Brown and FNB/IOM. Chapter 1 Overview of zinc Nutrition. Food and Nutrition Bulletin. The United Nations University. 2004; (S) 129-1.

6. Choua, G. Haloui, NE. Kari, $\mathrm{KE}$, Aguenaou, $\mathrm{H}$ and Mokhtar, N. Amount of zinc transferred in breast milk to breastfed moroccan babies with normal or low birth weight at 1, 3 and 6 months after birth. International Journal of Child Health and Nutrition. 2014; (3): 54-48.

7. Conita, DA. The growth differances og infant aged 3-6 months who were exclusively breastfed and who were not exclusively breastfed 
Pontianak: Unversitas Tanjung Pura; 2014.

8. Dorea, JG. Is zinc a first limiting nutrient in human milk. Nutr Res.1993; (13): 666-659.

9. Hasselquist MB. Tata laksana ibu dan bayi pasca kelahiran. Jakarta: Prestasi Pustakarya; 2006.

10. Ikatan Dokter Anak Indonesia (IDAI). Tumbuh Kembang Anak dan Remaja. Buku Ajar I. Jakarta: CV Sagung Seto; 2005.

11. Kuncoro, MA. Bahar, B dan Salam, A. Pengaruh pemberian suplemen zink intrauterine terhadap berat badan anak di Kabupaten Takalar. Universitas Hasanuddin: FKM. 2013: 91.

12. Lestari, W. Margawati, A dan Rahfiludin, MZ. Faktor resiko stunting pada anak umur 6-24 bulan di Kecamatan Penanggalan Kota Subulussalam Provinsi Aceh. 2004; ISSN: 37-35.

13. Masrul. Kajian peranan sumber daya pengasuhan terhadap tumbuh kembang bayi usia 6-12 bulan pada keluarga etnik Minangkabau di perdesaan Provinsi Sumatera Bara (Disertasi). Surabaya: Universitas Air Langga; 2005.

14. Moersintowarti N. Baku Standard tumbuh kembang. Dalam Moersintowarti N, Titi S, Soetjiningsih, Hariyono S, IG. N. Gde Ranuh, Sambas. Editor. Tumbuh Kembang
Anak dan Remaja. Jakarta: Balai Penerbit FKUI; 2008.

15. Orun, E. Yalcin, SS. Aykut, O. Orhan, G and Morgil, GK. 2012. Zinc and copper concentrations in breastmilk at the second month of lactation. Indian Pediatrics. 2012; (49): 135-133.

16. Osredkar, J and Sustar, N. Copper and zinc, biological role and signifinance of coper/zinc imbalance. $\mathbf{J}$ Clinic Toxicol. 2011; (S3): 18-1.

17. Pollard, M. ASI. Jakarta: EGC; 2015.

18. Riset Kesehatan Dasar (Riskesdas). Badan Penelitian dan Pengembangan Kesehatan Kementerian Kesehatan RI; 2010.

19. Roesli, U. Bayi sehat berkat ASI Eksklusif. Jakarta: PT Alex Media Kumputindo; 2001.

20. Salgueiro, MJ. Zubillaga, MB. Lysionek, AE. Caro, RA. Weil,l R. Eng and Boccio, JR. The Role of Zinc in The Growth and Development of Children. J Nutr. 2002; (18): 510-519.

21. Schwartz, MW. Pedoman klinis pediatri. Jakarta:EGC; 2005.

22. Sezer, RG. Aydemir, G. Akcan, AB. Bayoglu, DS. Guran, $\mathrm{T}$ and Bozaykut, A. Effect of Breastfeeding on Serum Zinc Levels and Growth in Healthy Infants. Pediatrics. 2013; (8): 159163.

23. Shankar, AH. and Prasad, AS. Zinc and immune 
function: the biological basis

of altered resistance to infection. Am J ClinNutr. 1998; (68) :447S-463S.

24. Supariasa, I. Penilaian status gizi. Jakarta: EGC; 2001.

25. Supariasa, I. Penilaian status gizi. Jakarta: EGC; 2012.

26. Tanuwidjaya, S. Konsep umum tumbuh dan kembang. Dalam Moersintowarti, N. Titi, S. Soetjiningsih. Hariyono, S. IG. N. Gde Ranuh. dan Sambas. Editor. Tumbuh Kembang Anak dan Remaja. Jakarta: Balai Penerbit FKUI; 2008.

27. Xiang, M. Harbige, LS and Zetterström, R. Breast milk levels of zinc and $\omega-6$ polyunsaturated fattyacids and growth of healthy Chinese infants. Acta Paediatrica. 2007; (96) :390387. 